Jurnal Geocelebes Vol. 4 No. 2, Oktober 2020, 118 - 128

\title{
ANALISIS PERKIRAAN HARGA LAHAN MENGGUNAKAN SISTEM INFORMASI GEOGRAFIS DI KECAMATAN RUMPIN KABUPATEN BOGOR
}

\author{
Vini Yuliawati*, Iwan Setiawan, Lili Somantri \\ Pendidikan Geografi, Universitas Pendidikan Indonesia, Jl. Dr. Setiabudhi No.229, Isola, Kec. Sukasari, Kota \\ Bandung, Jawa Barat 40154, Indonesia. \\ *Corresponding author. Email: viniyuliawati12@upi.edu / viniyuliawati18@gmail.com
}

Manuscript received: 21 June 2020; Received in revised form: 4 August 2020; Accepted: 23 September 2020

\begin{abstract}
Abstrak
Pemetaan perkiraan harga lahan di Kecamatan Rumpin Kabupaten Bogor sangat diperlukan, mengingat kenaikan harga lahan sangat pesat seiring dengan pertumbuhan ekonomi. Pemetaan perkiraan harga lahan dipengaruhi oleh faktor tertentu yaitu data penggunaan lahan (sawah, pemukiman), aksesibilitas lahan positif (jalan, pendidikan, pemerintahan), dan aksesibilitas lahan negatif (sungai, industri, kuburan). Oleh karena itu perlunya meneliti harga lahan untuk memudahkan memberikan informasi penting dalam pengambilan keputusan. Tujuan dari penelitian ini adalah menganalisis parameter peta perkiraan harga lahan di Kecamatan Rumpin Kabupaten Bogor dan menganalisis peta perkiraan harga lahan di Kecamatan Rumpin Kabupaten Bogor. Metode penelitian yang digunakan adalah skor dan pembobotan dengan menggunakan pendekatan kualitatif dan kuantitatif. Penelitian berlangsung dalam beberapa tahap, yaitu tahap persiapan, tahap pemrosesan data dan tahap analisis data. Hasil pemetaan estimasi harga lahan dibagi menjadi 5 kelas harga lahan. Nilai lahan sangat tinggi memiliki luas 9,74 $\mathrm{km}^{2}$, nilai lahan tinggi $5,36 \mathrm{~km}^{2}$, nilai lahan sedang $20,94 \mathrm{~km}^{2}$, nilai lahan rendah $65,08 \mathrm{~km}^{2}$, dan nilai lahan sangat rendah $37,82 \mathrm{~km}^{2}$.
\end{abstract}

Kata Kunci: Harga lahan; pemetaan; Sistem Informasi Geografis.

\begin{abstract}
Mapping land prices estimation in the Rumpin District Bogor Regency is very necessary, due to economic growth. Land price mapping which consists of several parameters, like Land Use data (rice fields, settlements), Positive Land Accessibility (roads, education, government), and Negative Land Accessibility (rivers, industry, cemeteries). Therefore it is necessary to examine estimates of land prices to make it easier to provide important information in decision making. The purpose of this study was to analyze the parameters of the estimated land price map in the Rumpin District Bogor Regency and analyze the map of the estimated price of land in the district of Rumpin District Bogor Regency. The research method used is a score and weighting using qualitative and quantitative. The study was conducted in three stages, namely the preparation phase, the data processing stage and the data analysis stage. The results of the mapping of land price estimates are divided into 5 land price classes. Very high land value have area $9.74 \mathrm{~km}^{2}$, high land value $5.36 \mathrm{~km}^{2}$, medium land value $20.94 \mathrm{~km}^{2}$, low land value $65.08 \mathrm{~km}^{2}$, very low land value $37.83 \mathrm{~km}^{2}$.
\end{abstract}

Keywords: Geographic Information Systems; land prices; mapping. 


\section{Pendahuluan}

Perkembangan teknologi informasi yang pesat telah merambah luas salah satunya terkait nilai harga lahan. Perkembangan teknologi informasi dalam hal ini Sistem Informasi Geografis (SIG) merupakan salah satu contoh dari kemajuan di bidang keilmuan dan teknologi. Oleh karena itu semakin banyak pihak atau instansi pemerintahan yang membutuhkan data spasial/ geografis sebagai salah satu data olahan yang penting untuk dijadikan suatu pengambilan keputusan (Fachrozy dkk., 2016).

Pentingnya kebutuhan lahan ini perlu dianalisis dengan SIG untuk mengetahui perkiraan harga lahan yang ada di Kecamatan Rumpin Kabupaten Bogor. Pemetaan perkiraan harga lahan yang terdiri dari beberapa parameter yaitu penggunaan lahan, aksesibilitas lahan positif, aksesibilitas lahan negatif. Penggunaan lahan yaitu salah satu parameter penting untuk menentukan perkiraan harga lahan yaitu sawah, pemukiman, lahan kosong, tegalan dan sawah. Aksesibilitas lahan positif yaitu memiliki nilai lahan yang lebih tinggi serta berpengaruh secara positif yaitu jalan arteri, jalan kolektor, jalan lokal, lembaga pendidikan, dan lembaga pemerintahan. Aksesibilitas lahan negatif yaitu memiliki nilai lahan yang rendah serta berpengaruh negatif yaitu sungai, industri, kuburan. Parameter tersebut merupakan faktor utama untuk penentuan harga lahan suatu daerah (Hidayati, 2013).

Pembahasan mengenai analisis harga lahan menggunakan aplikasi sistem informasi geografis dapat menjadi informasi yang sangat penting untuk dapat mengetahui penyajian harga lahan yang ditentukan oleh faktor sosial yaitu perkembangan penduduk. Hal ini mendorong masyarakat untuk mencari alternatif daerah untuk dijadikan sebagai pusat kegiatan perdagangan, jasa, maupun ekonomi lainnya. Oleh karena itu diperlukan suatu kajian tentang estimasi harga lahan menggunakan Sistem Informasi Geografis.

\section{Rumusan Masalah}

Adapun rumasalah dari penelitian ini adalah sebagai berikut:

a) Bagaimana parameter peta perkiraan harga lahan di Kecamatan Rumpin Kabupaten Bogor?

b) Bagaimana peta perkiraan harga lahan di Kecamatan Rumpin Kabupaten Bogor?

\section{Tujuan Penelitian}

Tujuan penelitian pada paper ini adalah sebagai berikut:

a) Menganalisis parameter peta perkiraan harga lahan di Kecamatan Rumpin Kabupaten Bogor.

b) Menganalisis peta perkiraan harga lahan di Kecamatan Rumpin Kabupaten Bogor.

\section{Studi Literatur}

\section{Lahan}

Lahan dapat diartikan sebagai komoditas untuk dimanfaatkan, dimiliki, diperjualbelikan, untuk kesenangan atau keuntungan pribadi. Lahan dianggap sumber daya milik bersama, seperti udara atau air, yang harus dijaga dan dipelihara dengan memperhatikan secara tepat dampaknya terhadap masyarakat sebagai keseluruhan dan pada kondisi saat sumber daya alam milik bersama akan diwariskan pada generasi mendatang (Anthony dan Snyder, 1989).

Menurut Yunus (2000) semakin tinggi aksesibilitas suatu lokasi semakin tinggi pula harga tanah. Sedangkan menurut Siswanto (2007) jarak dan kualitas lingkungan adalah parameter yang mempengaruhi harga tanah pada suatu lokasi. Jarak dalam pengertian ini berarti kemudahan menuju pusat aktivitas masyarakat umum seperti tempat kerja, 
tempat perdagangan, akses transportasi, fasilitas pelayanan pendidikan dan pelayanan kesehatan. Sedang kualitas lingkungan yang dimaksud seperti kepadatan perumahan, kondisi permukiman dan lain lain.

\section{Sistem Informasi Geografis}

Sistem Informasi Geografis (SIG) merupakan sistem komputer yang digunakan untuk mengumpulkan, memeriksa, mengintegrasikan, serta menganalisa informasi-informasi yang kaitannya dengan permukaan bumi (Prahasta, 2002). Istilah SIG yaitu gabungan dari ketiga unsur pokok yaitu sistem, informasi, dan geografi.

Subsistem yang dimiliki oleh SIG yaitu data input, data output, data management, data manipulasi dan analisis (Wibowo, 2015). Penjelasannya sebagai berikut:

a. Data input: memiliki tugas untuk mengumpulkan data spasial dan data atribut dari berbagai sumber lalu mempersiapkannya.

b. Data output: memiliki tugas untuk mengeluarkan output sebagian atau seluruh basis data, dalam bentuk softcopy maupun hardcopy seperti tabel, grafik, peta, dan lain-lain.

c. Data management: bertugas untuk mengatur data spasial maupun atribut ke dalam basis data hingga mudah dipanggil, dan diedit.

d. Data manipulasi dan analisis: bertugas untuk menentukan informasi yang akan dihasilkan. Selain itu, juga dapat memanipulasi dan memodelkan data untuk mendapatkan informasi yang diinginkan.

\section{Metode Penelitian}

\section{Lokasi Penelitian}

Penelitian dilakukan di Kecamatan Rumpin Kabupaten Bogor. Kecamatan Rumpin memiliki luas sekitar 13.708,57 hektar (Gambar 1). Adapun batas administratif :

a. Sebelah Utara : Kecamatan

Parungpanjang

b. Sebelah Barat : Kecamatan Cigudeg

c. Sebelah Selatan : Kecamatan

Leuwisadeng dan Kecamatan

Cibungbulang

d. Sebelah Timur : Kecamatan Ciseeng

\section{Metode Penelitian}

Metode yang digunakan adalah metode studi pustaka yaitu kajian teoritis dan referensi lain yang berhubungan dengan nilai, budaya dan norma yang berkembang pada situasi sosial yang diteliti. Studi pustaka sangat penting sebab penelitian memerlukan literatur ilmiah (Isnaeni, 2017). Penelitian ini menggunakan pendekatan kualitatif dan kuantitatif. Pendekatan kualitatif adalah bentuk penelitian yang dalam pengumpulan dan analisis datanya mengugunakan data dari informan dan peneliti menjadi bagian dari informan tersebut (Wahidmurni, 2017a). Sedangkan kuantitatif menekankan visualisasi data berupa angka dan program statistik dalam menjawab suatu masalah (Wahidmurni, 2017b).

Alat dan bahan yang digunakan yaitu shapefile Badan Infromasi Geospasial dan software ArcMap 10.3 untuk pemrosesan Sistem Informasi Geografis. 


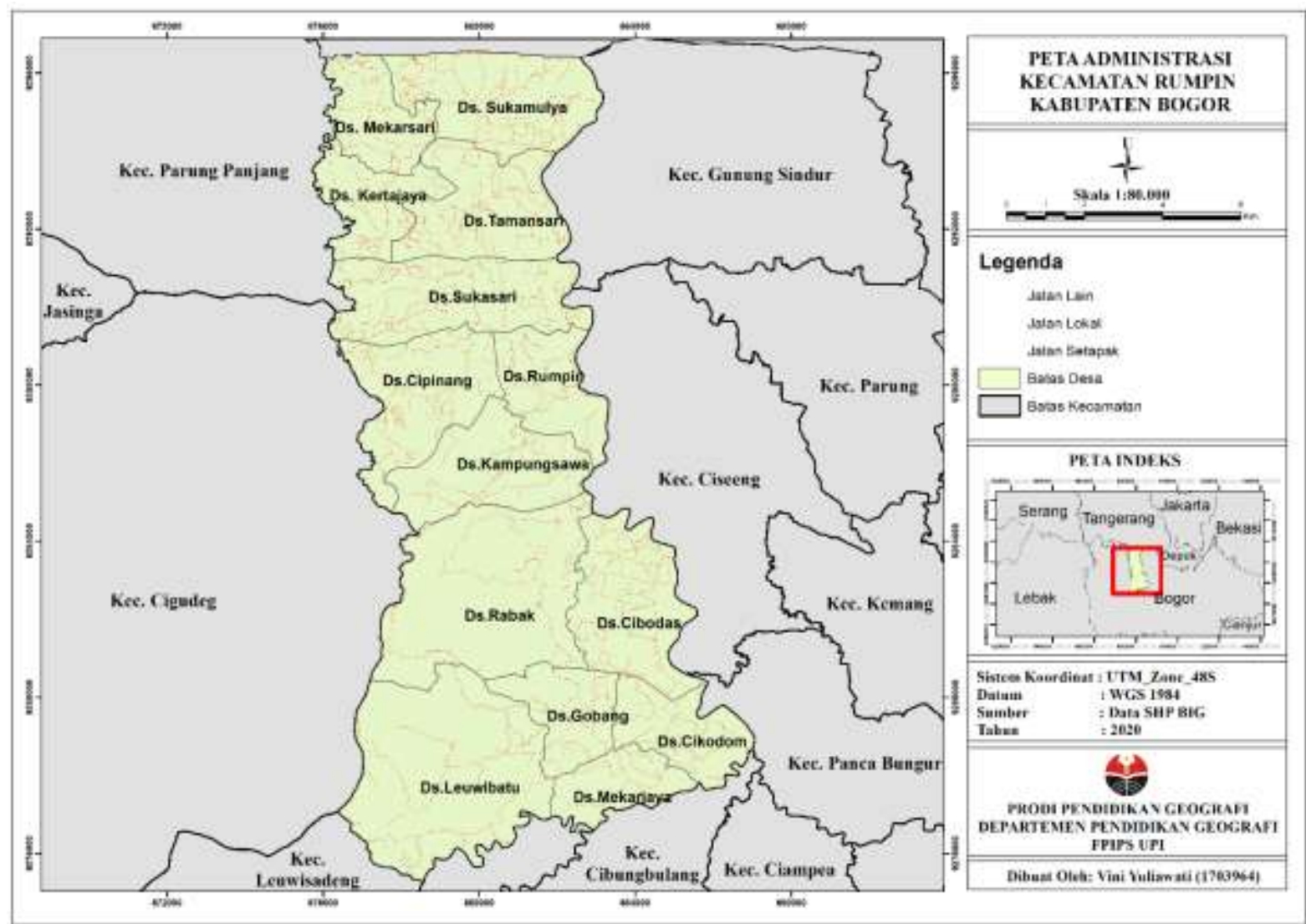

Gambar 1. Peta Administrasi Kecamatan Rumpin Kabupaten Bogor.

\section{Analisis Data}

Penelitian dilakukan dalam tiga tahap, yaitu tahap persiapan seperti menyiapakan sumber data, tahap pemrosesan data dan tahap analisis yang dapat dilihat pada Gambar 2. Adapun Tabel 1 - 4 merupakan parameter yang digunakan dalam proses pengharkatan dan pembobotan pada penelitian ini diantaranya adalah sebagai berikut:

Tabel 1. Klasifikasi dan harkat penggunaan lahan (Hidayati, 2013).

\begin{tabular}{c|c|c|c}
\hline No & Penggunaan Lahan & Kelas & Harkat \\
\hline 1 & Perdagangan dan Jasa & I & 4 \\
\hline 2 & Permukiman dan Industri & II & 3 \\
\hline 3 & Lahan Kosong & III & 2 \\
\hline 4 & Sawah dan Tegalan & IV & 1 \\
\hline
\end{tabular}

Tabel 2. Klasifikasi dan harkat aksesibilitas lahan positif (Hidayati, 2013).

\begin{tabular}{|c|c|c|c|c|}
\hline No & $\begin{array}{c}\text { Aksesibilitas Lahan } \\
\text { Positif }\end{array}$ & $\begin{array}{l}\text { Kriteria } \\
(\mathrm{m})\end{array}$ & Kelas & Harkat \\
\hline 1 & $\begin{array}{l}\text { Jarak terhadap jalan } \\
\text { arteri }\end{array}$ & $\begin{array}{c}<50 \\
50-150 \\
150- \\
500 \\
>500\end{array}$ & $\begin{array}{c}\text { I } \\
\text { II } \\
\text { III } \\
\text { IV }\end{array}$ & $\begin{array}{l}4 \\
3 \\
2 \\
1\end{array}$ \\
\hline 2 & $\begin{array}{c}\text { Jarak terhadap jalan } \\
\text { kolektor }\end{array}$ & $\begin{array}{c}<50 \\
50-150 \\
150- \\
500 \\
>500 \\
\end{array}$ & $\begin{array}{l}\text { I } \\
\text { II } \\
\text { III } \\
\text { IV }\end{array}$ & $\begin{array}{l}4 \\
3 \\
2 \\
1\end{array}$ \\
\hline 3 & $\begin{array}{c}\text { Jarak terhadap jalan } \\
\text { lokal }\end{array}$ & $\begin{array}{c}50 \\
50-150 \\
150- \\
500 \\
>500\end{array}$ & $\begin{array}{l}\text { I } \\
\text { II } \\
\text { III } \\
\text { IV }\end{array}$ & $\begin{array}{l}4 \\
3 \\
2 \\
1\end{array}$ \\
\hline 4 & $\begin{array}{c}\text { Jarak terhadap } \\
\text { lembaga pendidikan }\end{array}$ & $\begin{array}{c}<200 \\
200- \\
500 \\
>500 \\
\end{array}$ & $\begin{array}{l}\text { I } \\
\text { II } \\
\text { III }\end{array}$ & $\begin{array}{l}3 \\
2 \\
1\end{array}$ \\
\hline 5 & $\begin{array}{l}\text { Jarak terhadap } \\
\text { lembaga } \\
\text { pemerintahan }\end{array}$ & $\begin{array}{c}<200 \\
200- \\
500 \\
>500\end{array}$ & $\begin{array}{c}\text { I } \\
\text { II } \\
\text { III }\end{array}$ & $\begin{array}{l}3 \\
2 \\
1\end{array}$ \\
\hline
\end{tabular}




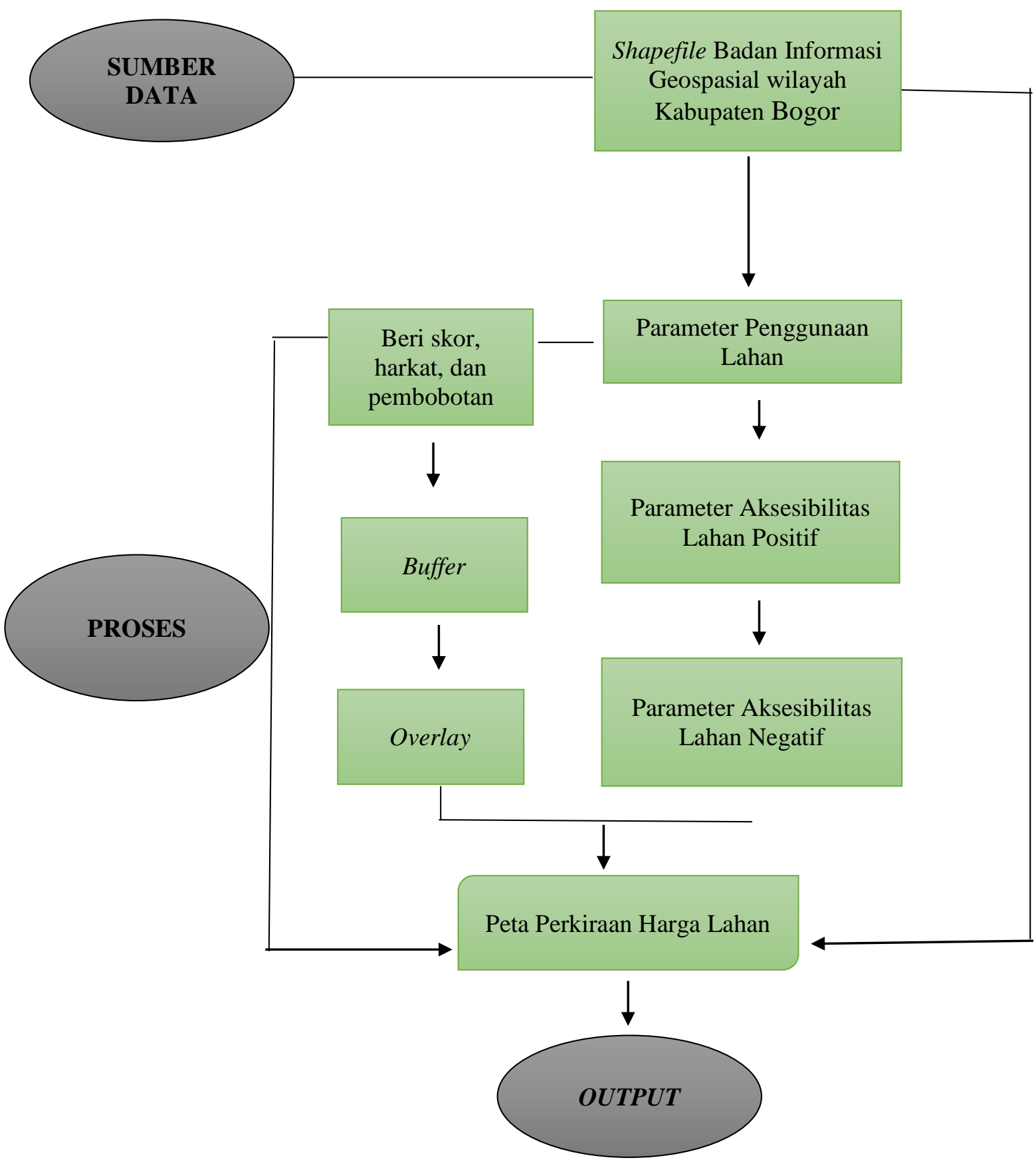

Gambar 2. Diagram Alir Penelitian.

Tabel 3. Klasifikasi dan Aksesibilitas Lahan Negatif (Hidayati, 2013).

\begin{tabular}{c|c|c|c|c}
\hline \multirow{2}{*}{ No } & $\begin{array}{c}\text { Aksesibilitas Lahan } \\
\text { Negatif }\end{array}$ & $\begin{array}{c}\text { Kriteria } \\
(\mathrm{m})\end{array}$ & Kelas & Harkat \\
\hline \multirow{2}{*}{1} & Jarak terhadap & $<200$ & I & 2 \\
& sungai & $>200$ & II & 1 \\
\hline \multirow{2}{*}{2} & Jarak terhadap & $<200$ & I & 2 \\
& sumber pousi & $>200$ & II & 1 \\
\hline \multirow{2}{*}{3} & Jarak terhadap & $<200$ & I & 2 \\
& kuburan & $>200$ & II & 1 \\
\hline
\end{tabular}

Tabel 4. Nilai bobot faktor penentu harga lahan (Hidayati, 2013).

\begin{tabular}{c|l|c}
\hline No & Faktor penentu Harga Lahan & $\begin{array}{c}\text { Nilai } \\
\text { Bobot }\end{array}$ \\
\hline 1 & Penggunaan Lahan & 3 \\
\hline 2 & Aksesibilitas Lahan Positif & 2 \\
\hline 3 & Aksesibilitas Lahan Negatif & -1 \\
\hline 4 & Kelengkapan Fasilitas Umum & 1 \\
\hline
\end{tabular}




\section{Hasil dan Pembahasan}

\section{Parameter Penggunaan lahan}

Penggunaan lahan diartikan sebagai dampak aktivitas manusia di permukaan bumi pada suatu wilayah yang dipengaruhi kondisi alam, kegiatan sosial-ekonomi dan budaya setempat (Hanifati, 2016).

Berdasarkan klasifikasi dan harkat penggunaan lahan yang terdapat pada Tabel 1, untuk pembuatan peta parameter penggunaan lahan terdiri dari beberapa penggunaan lahan, di sini penulis membuat peta parameter penggunaan lahan yaitu pemukiman dan sawah dengan masingmasing telah diberi pengharkatan dan pembobotan.

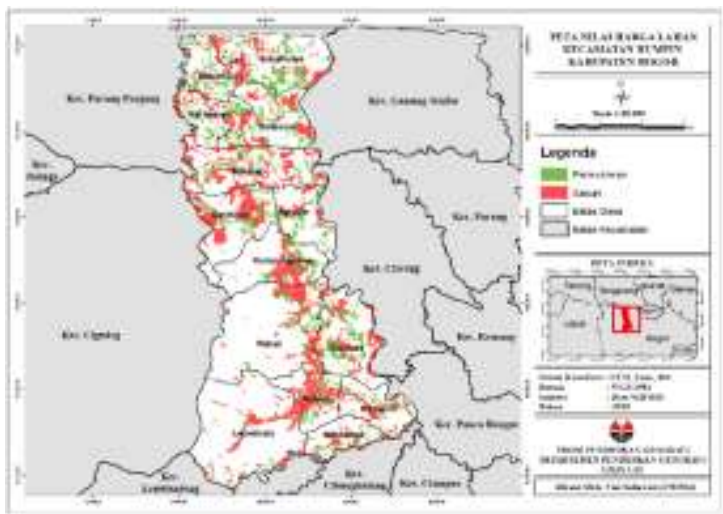

Gambar 3. Peta penggunaan lahan.

Penggunaan lahan merupakan faktor yang paling berpengaruh terhadap harga lahan. Semakin dekat lahan dengan pusat aktivitas manusia maka harga lahan semakin meningkat. Selain itu penggunaan lahan juga dipengaruhi oleh kesuburan lahan tersebut. Semakin subur suatu lahan maka harga lahan lebih tinggi sebab memberikan output yang lebih banyak.

Peta penggunaan lahan yang terdapat pada Gambar 3. menunjukkan adanya lahan pemukiman dan sawah dengan masingmasing telah diberikan pengharkatan dan pembobotan. Sehingga dapat menentukan faktor penyebab tinggi atau rendahnya suatu lahan. Penggunaan sawah memiliki luas 23 ha dan lahan permukiman memiliki luas 15 ha.

\section{Parameter Aksesibilitas Lahan Positif}

1. Jaringan Jalan

Kondisi jalan menentukan tingkat kenyamanan pengguna jalan pada suatu perumahan. Selain itu dengan adanya parameter jalan, ketersediaan angkutan umum akan memberikan kemudahan bagi penghuni perumahan dalam melakukan pencapaian terhadap tempat-tempat untuk melakukan aktifitas serta memnuhi kebutuhannya. Dilihat dari kondisi jalan yang baik dapat memberikan tingkat pelayanan yang lebih baik bagi masyarakat dalam berlalu lintas.

Pada Gambar 4 menunjukan peta jaringan jalan di Kecamatan Rumpin Kabupaten Bogor yang telah dilakukan proses pengharkatan, buffering dan pembobotan. Warna merah dengan jarak terhadap jalan $750 \mathrm{~m}$, warna orange dengan jarak terhadap jalan $450 \mathrm{~m}$, warna hijau muda dengan jarak terhadap jalan $145 \mathrm{~m}$, dan warna hijau tua dengan jarak terhadap jalan $45 \mathrm{~m}$.

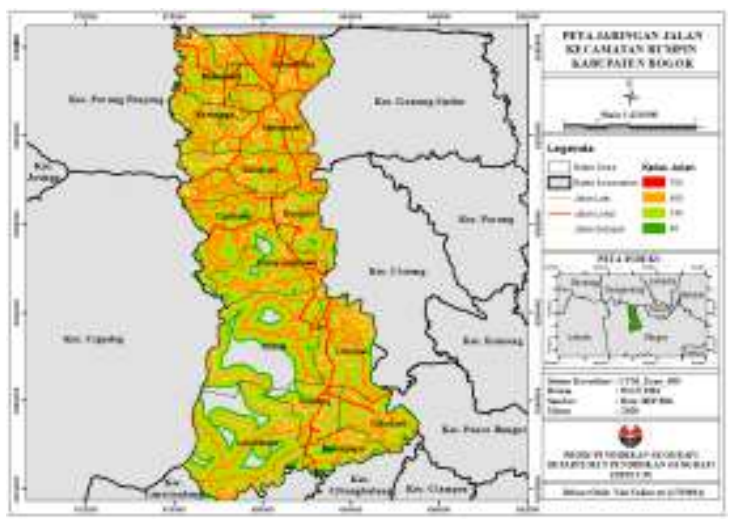

Gambar 4. Peta jaringan jalan.

Masing-masing kelas jalan tersebut dari hasil pengharkatan dan pembobotan. Sehingga mendapatkan informasi jarak terhadap jalan dengan menghasilkan kelas jalan. Pada jarak $45 \mathrm{~m}$ memiliki luas 32 $\mathrm{km}^{2}$, jarak $145 \mathrm{~m}$ memiliki luas $36 \mathrm{~km}^{2}$, jarak $450 \mathrm{~m}$ memiliki luas $55 \mathrm{~km}^{2}$, dan jarak $750 \mathrm{~m}$ memiliki luas $6 \mathrm{~km}^{2}$. 


\section{Pendidikan}

Pendidikan merupakan salah satu faktor penting sehingga keberadaannya dapat diharapkan banyak masyarakat agar dapat mendidik anaknya dengan masuknya ke sekolah atau perguruan tinggi di sekitar rumahnya.

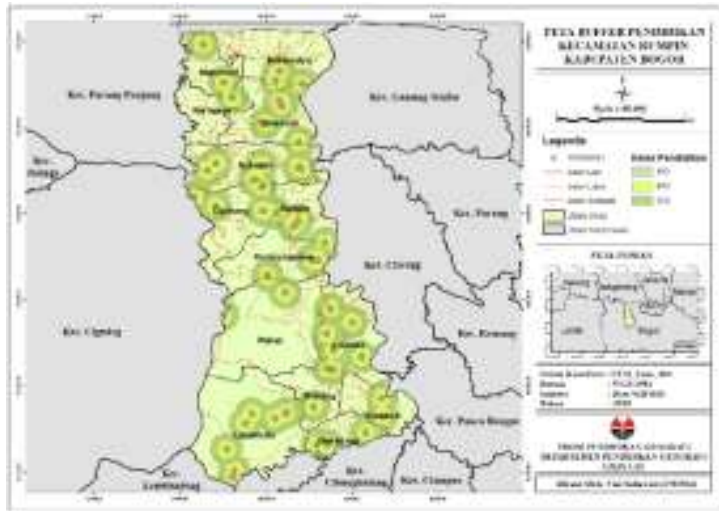

Gambar 5. Peta buffer pendidikan.

Pada Gambar 5 menunjukan peta buffer pendidikan di Kecamatan Rumpin Kabupaten Bogor yang telah dilakukan proses buffering, pembobotan, serta pengharkatan. Terdapat tiga kelas dengan masing-masing telah terdapat jarak terhadap lembaga pendidikan. Warna hijau muda dengan jarak terhadap pendidikan $180 \mathrm{~m}$, warna kuning dengan jarak terhadap pendidikan $450 \mathrm{~m}$, dan warna hijau tua dengan jarak terhadap pendidikan yaitu 750 $\mathrm{m}$. Masing-masing kelas pendidikan tersebut dari hasil pengharkatan, pembobotan, dan buffering. Sehingga mendapatkan informasi jarak terhadap pendidikan dengan menghasilkan kelas jalan. Jarak $180 \mathrm{~m}$ memiliki luas $5 \mathrm{~km}^{2}$, jarak $450 \mathrm{~m}$ memiliki luas $22 \mathrm{~km}^{2}$, dan jarak $750 \mathrm{~m}$ memiliki luas $33 \mathrm{~km}^{2}$.

\section{Pemerintahan}

Pemerintahan merupakan salah satu faktor penting dalam menentukan peta estimasi harga lahan, karena dengan adanya lembaga pemerintahan dekat dengan perumahan, masyarakat akan lebih mudah untuk mengurus pengarsipan seperti lembaga pemerintahan kantor camat, bank, dan lain sebagainya.

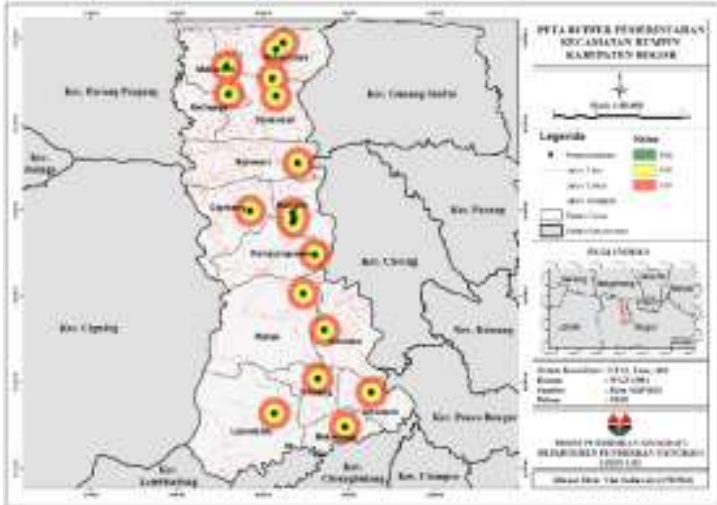

Gambar 6. Peta buffer pemerintahan.

Gambar 6 menunjukkan peta buffer pemerintahan di Kecamatan Rumpin Kabupaten Bogor yang telah dilakukan proses buffering, pengharkatan, dan pembobotan. Terdapat tiga kelas dengan masing-masing telah terdapat jarak terhadap lembaga pemerintahan. Warna hijau dengan jarak terhadap lembaga pemerintahan $190 \mathrm{~m}$, warna kuning dengan jarak terhadap lembaga pemerintahan 450 $\mathrm{m}$, dan warna merah dengan jarak terhadap lembaga pemerintahan $750 \mathrm{~m}$. Masingmasing kelas pemerintahan tersebut dari hasil pengharkatan, pembobotan, dan buffering. Jarak $190 \mathrm{~m}$ memiliki luas $2 \mathrm{~km}^{2}$ jarak $450 \mathrm{~m}$ memiliki luas $8 \mathrm{~km}^{2}$, dan jarak $750 \mathrm{~m}$ memiliki luas $17 \mathrm{~km}^{2}$.

\section{Parameter Aksesibilitas Lahan Negatif}

\section{Sungai}

Masyarakat lebih menginginkan lahan yang jauh dari sungai, sebab menghindari banjir atau dampak negatif sungai lainnya. Sehingga parameter sungai berdampak negatif terhadap lahan.

Gambar 7 menunjukkan peta buffer sungai di Kecamatan Rumpin Kabupaten Bogor yang telah dilakukan proses buffering, pengharkatan, dan pembobotan. Terdapat dua kelas dengan masing-masing telah terdapat jarak terhadap sungai. Warna hijau dengan jarak terhadap sungai $190 \mathrm{~m}$, warna merah dengan jarak terhadap sungai $500 \mathrm{~m}$. Masing-masing kelas sungai tersebut dari hasil pengharkatan, pembobotan, dan buffering. Sehingga mendapatkan 
informasi jarak terhadap sungai dengan menghasilkan kelas sungai. Jarak $190 \mathrm{~m}$ memiliki luas $109 \mathrm{~km}^{2}$ dan jarak $500 \mathrm{~m}$ memiliki luas $25 \mathrm{~km}^{2}$.

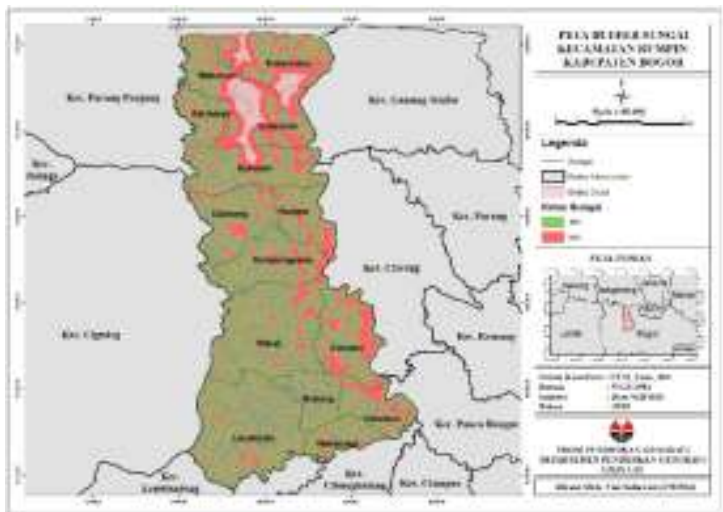

Gambar 7. Peta buffer sungai.

\section{Sumber Polusi/ Industri}

Parameter lainnya yang termasuk pada aksesibilitas lahan negatif yaitu sumber polusi/ industri. Industri menjadi sumber polusi yang tidak menguntungka bagi suatu lahan karena memberikan dampak negatif. Dengan adanya industri sebagai sumber polusi pada perumahan di sekitarnya dapat membuat ketidanyamanan untuk memilih lahan di wilayah dekat dengan industri.

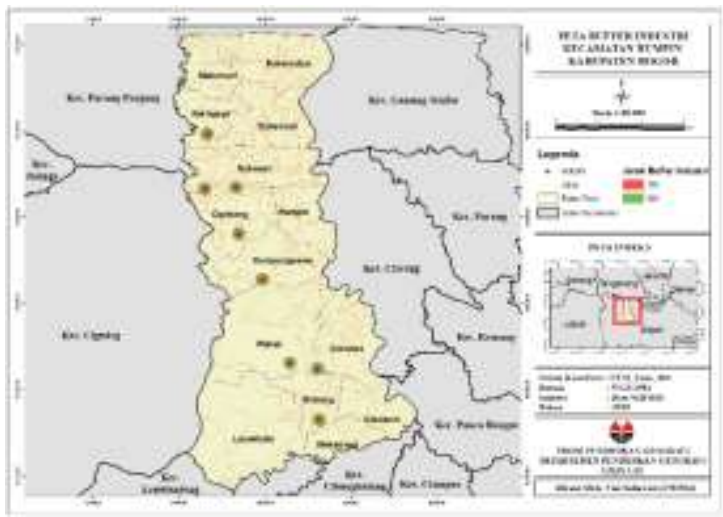

Gambar 8. Peta buffer industri.

Gambar 8 menunjukkan peta buffer industri di Kecamatan Rumpin Kabupaten Bogor yang telah dilakukan proses buffering, pengharkatan, dan pembobotan. Terdapat dua kelas dengan masing-masing telah terdapat jarak terhadap industri. Warna merah dengan jarak terhadap industri 190 $\mathrm{m}$, warna hijau dengan jarak terhadap industri $500 \mathrm{~m}$. Masing-masing kelas industri tersebut dari hasil pengharkatan, pembobotan, dan buffering. Jarak $190 \mathrm{~m}$ memiliki luas $0,91 \mathrm{~km}^{2}$ dan jarak $500 \mathrm{~m}$ memiliki luas $0,135 \mathrm{~km}^{2}$.

\section{Makam}

Faktor psikologis menyebabkan masyarakat memilih lahan di wilayah yang jauh dari makam. Sehingga parameter ini berdampak negatif terhadap lahan.

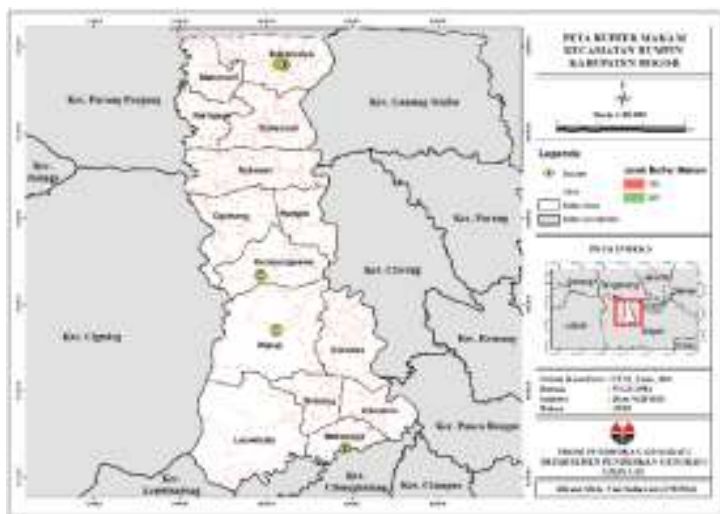

Gambar 9. Peta buffer makam.

Pada Gambar 9 menunjukkan peta buffer makam di Kecamatan Rumpin Kabupaten Bogor yang telah dilakukan proses buffering, pengharkatan, dan pembobotan. Terdapat dua kelas dengan masing-masing telah terdapat jarak terhadap makam. Warna merah dengan jarak terhadap makam 190 m, warna hijau dengan jarak terhadap makam $500 \mathrm{~m}$. Masing-masing kelas makam tersebut dari hasil pengharkatan, pembobotan, dan buffering. Jarak $190 \mathrm{~m}$ memiliki luas $0,22 \mathrm{~km}^{2}$, dan jarak $300 \mathrm{~m}$ memiliki luas $0,28 \mathrm{~km}^{2}$.

\section{Perkiraan Harga Lahan}

Pemetaan perkiraan harga lahan di Kecamatan Rumpin Kabupaten Bogor sangat diperlukan, mengingat kenaikan harga lahan sangat pesat seiring dengan pertumbuhan ekonomi. Pemetaan harga lahan menggunakan parameter penggunaan lahan yaitu sawah, pemukiman, industri dengan masing-masing memiliki kelas dan harkat untuk menghasilkan data. 
Untuk menentukan suatu nilai lahan perlu adanya klasifikasi dan harkat aksesibilitas lahan positif seperti jalan, pendidikan, dan kantor pemerintahan dengan masingmasing telah memiliki kriteria yaitu dari < 50, 50 - 150, 150 - 500, > 500 dengan kelas dan harkat yang telah ditentukan. Lalu selain aksesibilitas lahan positif juga harus memperhatikan aksesibilitas lahan negatif yang juga telah memiliki kriteria yaitu dari
$<200$ dan > 200 dengan kelas dan harkat yang telah ditentukan. Selanjutnya agar menghasilkan beberapa kriteria harga lahan tentunya menggunakan nilai bobot faktor penentu harga lahan yaitu Penggunaan Lahan (3), Aksesibilitas Lahan Positif (2), Aksesibilitas Lahan Negatif (-1). Peta perkiraan harga lahan dapat dilihat pada Gambar 10.

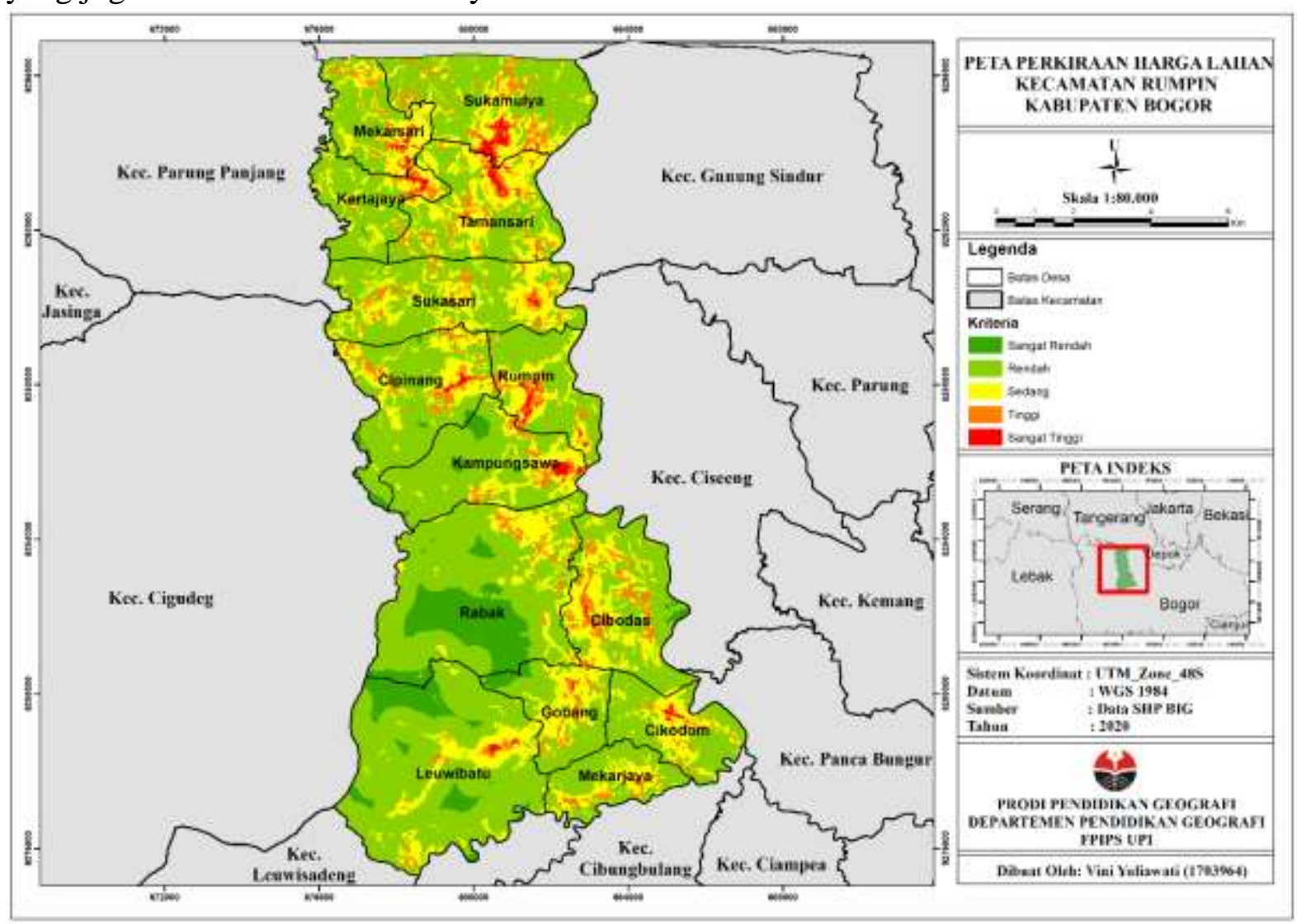

Gambar 10. Peta Perkiraan Harga Lahan.

Harga lahan kelas I (sangat tinggi) yang memiliki nilai lahan sangat tinggi. harga lahan kelas I terdapat di sepanjang jalan lokal dan jalan arteri dengan memiliki luas lahan $9,74 \mathrm{~km}^{2}$. Hal ini dipengaruhi karena di Kecamatan Rumpin terdapat fasilitas pendidikan, pemerintahan, dan memiliki jaringan jalan yang strategis karena letaknya dekat dengan jalan lokal dan jalan arteri, serta memiliki fasilitas tersedia yang lengkap.

Harga lahan kelas II (tinggi) yang memiliki luas lahan $5,36 \mathrm{~km}^{2}$ yang persebarannya terdapat di seluruh desa Kecamatan
Rumpin Kabupaten Bogor. Hal ini karena penggunaan lahan yang mendominasi adalah permukiman serta fasilitas yang memadai.

Harga lahan kelas III (sedang) yang memiliki luas lahan $20,94 \mathrm{~km}^{2}$. Hal ini karena memiliki lahan yang letaknya berdekatan dengan sungai maupun makam, namun di sisi lain pemukimannya pun mendukung.

Harga lahan kelas IV (rendah) yang memiliki nilai lahan yang rendah, hal ini dipengaruhi karena tempat tersebut 
merupakan lahan yang kurang menguntungkan, seperti lahan yang letaknya dekat dengan sungai dengan kemungkinan besar lahan tersebut akan tergenang banjir saat musim hujan ataupun letaknya dekat dengan sumber polusi seperti industri akan menyebabkan pencemaran udara dan kebisingan yang membuat kenyamanan menjadi terganggu, sehingga harga lahan menjadi rendah. Lahan rendah memiliki luas $65,08 \mathrm{~km}^{2}$.

Harga lahan kelas V (sangat rendah) yang memiliki nilai lahan sangat rendah dengan mayoritas terdapat di Desa Rabak dengan memiliki luas lahan $37,82 \mathrm{~km}^{2}$. Hal ini juga dipengaruhi karena banyak lahan yang memiliki aksesibilitas negatif yaitu di pinggir sungai, berdekatan dengan makam yang dapat menganggu psikologi, dan berdekatan dengan sumber polusi karena dapat mengganggu kenyamanan.

Peta perkiraan harga lahan di Kecamatan Rumpin Kabupaten Bogor terdapat 14 desa dengan mayoritas memiliki harga rendah dan minoritas harga lahan sangat tinggi. Namun seiring berjalannya waktu harga tanah akan mengalami perkembangan jika banyak faktor pemicu yang meningkatnya harga tanah serta adanya perpindahan fasilitias umum ke desa lain yang dapat menyebabkan perubahan harga tanah menjadi tinggi.

\section{Kesimpulan}

Dari penelitian ini dihasilkan beberapa kesimpulan diantaranya adalah sebagai berikut:

1. Kecamatan Rumpin memiliki luas sekitar 138,9585 $\mathrm{km}^{2}$, menghasilkan informasi perkiraan harga lahan dengan terbagi menjadi 5 kelas yaitu Lahan Sangat Rendah memiliki luas $37,82 \mathrm{~km}^{2}$, Lahan Rendah memiliki luas $65,08 \mathrm{~km}^{2}$, Lahan Sedang memiliki luas 20,94 km², Lahan Tinggi memiliki luas lahan $5,36 \mathrm{~km}^{2}$, dan
Lahan Sangat Tinggi memiliki luas lahan $9,74 \mathrm{~km}^{2}$.

2. Penggunaan lahan merupakan parameter yang paling mempengaruhi harga lahan. Semakin strategis lokasi suatu lahan maka harga lahan semakin tinggi.

\section{Ucapan Terima Kasih}

Ucapan terima kasih ditujukan kepada semua pihak yang telah membantu dalam pengambilan data baik dari jurnal maupun artikel ilmiah lainnya, serta dosen yang telah memberikan saran dan bimbingan dalam pembuatan jurnal ilmiah ini khususnya bimbingan peta.

\section{Daftar Pustaka}

Anthony, J. C. dan Snyder, C. 1989. Perencanaan Kota Edisi Kedua. Erlangga. Jakarta.

Fachrozy, A. P., Agus, F. dan Arifin, Z. 2016. Sistem Informasi Geografi Pemetaan Zona Nilai Tanah Kota Samarinda Menggunakan Framework Pmapper. Jurnal Prosiding Seminar Sains dan Teknologi FPMIPA Unmul Vol. 1 No. 1 Juli 2016, Samarinda, Indonesia.

Hanifati, S. F. 2016. Analisis Nilai Lahan di Kecamatan Mantrijeron Kota Yogyakarta Dengan Aplikasi Penginderaan Jauh dan Sistem Informasi Geografis. Skripsi, Universitas Muhammadiyah Surakarta.

Hidayati, I. N. 2013. Analisis Harga Lahan Berdasarkan Citra Penginderaan Jauh Resolusi Tinggi. Jurnal Pendidikan Geografi. 13(1), pp.5771.

Isnaeni, L. P. 2017. Bab III Metode Penelitian. UNPAS

Prahasta, E. 2002. Konsep-Konsep Dasar Sistem Informasi Geografis. Informatika. Bandung. 
Siswanto, E. 2007. Kajian Harga Lahan dan Kondisi Lokasi Lahan Pemrukiman di Kecamatan Arga Makmur Kabupaten Bengkulu Utara. Tesis, Universitas Diponegoro.

Wahidmurni. 2017a. Pemaparan Metode Penelitian Kualitatif. UIN Maulana Malik Ibrahim Malang.

Wahidmurni. 2017b. Pemaparan Metode Penelitian Kuantitatif. UIN Maulana Malik Ibrahim Malang.

Wibowo, K. M., Kanedi, I. dan Jumadi, J. 2015. Sistem Informasi Geografis (SIG) Menentukan Lokasi Pertambangan Batu Bara di Provinsi Bengkulu Berbasis Website. Jurnal Media Infotama 11(1), pp.51-60.

Yunus, H. S. 2000. Struktur Tata Ruang Kota. Yogyakarta: Fakultas Geografi, Universitas Gadjah Mada. 